\title{
Application of a Sulfur Removal Hydrometallurgical Process in a Lead-Acid Battery Recycling Plant in Costa Rica
}

\author{
Marta Navarro-Monge1, Germain Esquivel-Hernández ${ }^{1,2 *}$, José Pablo Sibaja Brenes ${ }^{1,2}$, \\ José Carlos Mora-Barrantes ${ }^{2}$, Ricardo Sánchez-Murillo², Juan Valdés-González ${ }^{1,2}$, \\ Pablo Bolaños-Ulloa ${ }^{3}$
}

\author{
${ }^{1}$ Atmospheric Laboratory, Chemistry Department, National University of Costa Rica, Heredia, Costa Rica \\ ${ }^{2}$ Chemistry Department, National University of Costa Rica, Heredia, Costa Rica \\ ${ }^{3} \mathrm{~Pb}$ Metals S.A., Cartago, Costa Rica \\ Email: *germain.esquivel.hernandez@gmail.com
}

How to cite this paper: Navarro-Monge, M., Esquivel-Hernández, G., Brenes, J.P.S., Mora-Barrantes, J.C., Sánchez-Murillo, R., Valdés-González, J. and Bolaños-Ulloa, P. (2017) Application of a Sulfur Removal Hydrometallurgical Process in a Lead-Acid Battery Recycling Plant in Costa Rica. Open Journal of Air Pollution, 6, 18-26. https://doi.org/10.4236/ojap.2017.61002

Received: January 29, 2017

Accepted: March 14, 2017

Published: March 17, 2017

Copyright $\odot 2017$ by authors and Scientific Research Publishing Inc. This work is licensed under the Creative Commons Attribution International License (CC BY 4.0).

http://creativecommons.org/licenses/by/4.0/

\begin{abstract}
This study presents the implementation of a desulphurization process for lead recycling under different chemical and physical conditions using pyro-metallurgical processes. Desulphurization was done using a hydrometallurgical process using sodium carbonate as a desulphurization agent and different leadbearing loads compositions. Waste characterization included: $\mathrm{SO}_{2}$ concentrations in the stack emissions, total lead content in the furnace ash, the total lead content in the slag, and the toxicity characteristic leaching procedure (TCLP). A significant reduction in $\mathrm{SO}_{2}$ emissions was achieved ( $\sim 55 \%$ reduction) where mean $\mathrm{SO}_{2}$ concentrations changed from $2193 \pm 135 \mathrm{ppm}$ to 1006 $\pm 62 \mathrm{ppm}$ after the implementation of the modified processes. The desulfurized lead paste (i.e. the metallic fraction lead of the battery) of the modified process exhibited an improvement in the concentration of the lead in the TCLP test, with an average value of $1.5 \mathrm{ppm}$ which is below US EPA limit of 5 $\mathrm{ppm}$. The traditional process TCLP mean value for the TCLP was $54.2 \mathrm{ppm}$. The total lead content in the bag house ashes shows not significant variations, when comparing the desulphurization $(67.6 \% \mathrm{~m} / \mathrm{m})$ and non-desulphurization process $(64.9 \% \mathrm{~m} / \mathrm{m})$. The total lead mean content in the slag was higher in the desulphurization process $(2.49 \% \mathrm{~m} / \mathrm{m})$ than the traditional process $(1.91 \%$ $\mathrm{m} / \mathrm{m}$ ). Overall, the implementation of a new desulphurization method would potentially increase the operation costs in $10.3 \%$. At the light of these results, a combination of hydrometallurgical and pyro-metallurgical processes in the recycling of lead-acid batteries can be used to reduce the environmental impact of these industries but would increase the operational costs of small lead recyclers.
\end{abstract}




\section{Keywords}

Lead-Acid Battery Recycling, Hydrometallurgical and Pyro-Metallurgical Processes, Hazardous Waste Management

\section{Introduction}

Lead-acid batteries belong to a group of commercial products that can become a potential hazardous waste after their use. Lead recovery from lead-acid batteries is the type of business that combines environmental protection and economic profits. The largest component of the lead-acid battery is the so-called metallic fraction lead or lead paste $(60 \%-75 \%)$ that is obtained during the processing of battery scrap. The other components are comprised of electrolytes and various types of plastics. Lead paste is primarily a mixture of $\mathrm{PbSO}_{4}, \mathrm{PbO}_{2}, \mathrm{~Pb}_{2} \mathrm{O}, \mathrm{Pb}_{2} \mathrm{O}_{3}$ and metallic lead. $\mathrm{PbSO}_{4}$ is the main lead carrier in the battery paste (40\%). It is formed during the battery operation as a result of the reaction of metallic $\mathrm{Pb}$ and $\mathrm{PbO}_{2}$ with the electrolyte (i.e. aqueous solution of sulphuric acid IV) [1] [2] [3].

Raw lead is obtained by melting the metallic fraction to achieve a reduction of the lead compounds (i.e. mainly $\mathrm{PbSO}_{4}$ and $\mathrm{PbO}$ ) [1] [4] [5]. At the smelting step, named pyro-metallurgical process, the lead compounds are reduced to metallic lead by smelting the battery paste (i.e. lead oxides with a small amount of lead sulfate) using reducing agents rich in carbon, cast iron $(\mathrm{Fe})$, and sodium carbonate $\left(\mathrm{Na}_{2} \mathrm{CO}_{3}\right)$ for the removal of other metals (e.g. $\left.\mathrm{Cu}, \mathrm{Sn}, \mathrm{As}, \mathrm{Ag}\right)$ in the oxide form. This reduction process leads to the formation of sulfides, named lead slag, as well as other gases and particulate matter emissions. The equipment used is a rotary furnace, short or long, to minimize the amount of waste, along with emissions control systems, such as bag houses for the filtration and recovery of the lead-rich particulate matter [6].

As a result of the battery paste melting process, a fraction of the sulfur is transferred into the slag in the form of sulfides, and the remaining large portion is oxidized to sulfur dioxide. Recently, national and international environmental agencies have updated the environmental legislation and have implemented new emissions limits that seek a reduction of the $\mathrm{SO}_{2}$ emissions into the atmosphere. For example, the Basel Convention has enforced secondary lead producers to take actions in order to decrease $\mathrm{SO}_{2}$ emissions. One available method to prevent large $\mathrm{SO}_{2}$ emissions relies on the desulphurization of the battery paste before melting [1] [2] [3] [4]. The most common process in desulphurization of battery paste includes the application of caustic soda $(\mathrm{NaOH})$ or sodium carbonate $\left(\mathrm{Na}_{2} \mathrm{CO}_{3}\right)$ solutions. [1] [5]-[10].

The sodium carbonate method is commonly used for desulphurization of battery paste when the sulfur content is less than $1 \%$. This method converts the sulfur present in the paste into sodium sulphate using sodium carbonate as a desulphurization agent. Consequently, a desulphurized paste and soluble sodium sulphate is obtained. Equation (1) describes the chemical reaction in the desul- 


$$
\begin{aligned}
& \text { phurization step [1] [4] [5]: } \\
& \qquad \mathrm{PbSO}_{4(\mathrm{~s})}+\mathrm{Na}_{2} \mathrm{CO}_{3(\mathrm{aq})} \rightarrow \mathrm{PbCO}_{3(\mathrm{~s})}+\mathrm{Na}_{2} \mathrm{SO}_{4(\mathrm{aq})}
\end{aligned}
$$

To achieve high efficiency in the desulphurization process, the reaction must be carried out using an excess of carbonate. Therefore, an excess of sodium carbonate is added and later neutralized according to Equation (2) [1] [4] [5]:

$$
\mathrm{H}_{2} \mathrm{SO}_{4(\mathrm{aq})}+\mathrm{Na}_{2} \mathrm{CO}_{3(\mathrm{aq})} \rightarrow \mathrm{Na}_{2} \mathrm{SO}_{4(\mathrm{aq})}+\mathrm{CO}_{2(\mathrm{~g})}+\mathrm{H}_{2} \mathrm{O}_{(\mathrm{l})}
$$

There is only one major organization, PB Metals S.A., producing lead metal in Costa Rica. PB Metals uses only scrap battery. The production capacity of PB Metals during 2016 is 4500 ton per year of secondary lead, being this production exported entirely to Colombia. This study presents the implementation of a desulphurization process of lead paste under different chemical and physical conditions in a smelting furnace, before its conversion into metallic lead. The aims of the study was: i) to implement a desulphurization process for lead paste using a hydrometallurgical process and sodium carbonate as desulphurization agent, ii) to make a waste characterization of the traditional process (i.e. the pyro-metallurgical process) and the hydrometallurgical modified process which includes total lead content in the sulphidic slag, the lead content in the bag house ashes, the toxicity characteristic leaching properties of the slag using the TCLP test, and the $\mathrm{SO}_{2}$ concentrations in the stack emissions, iii) to estimate the change in operational costs after the implementation of the new hydrometallurgical process (Figure 1).

\section{Materials and Methods}

The experimental approach of this work was similar to that reported by Lewis and Beautement (2002) [11] that used a characterization of the waste to facilitate the overall process understanding and to aid the identification of process defi-

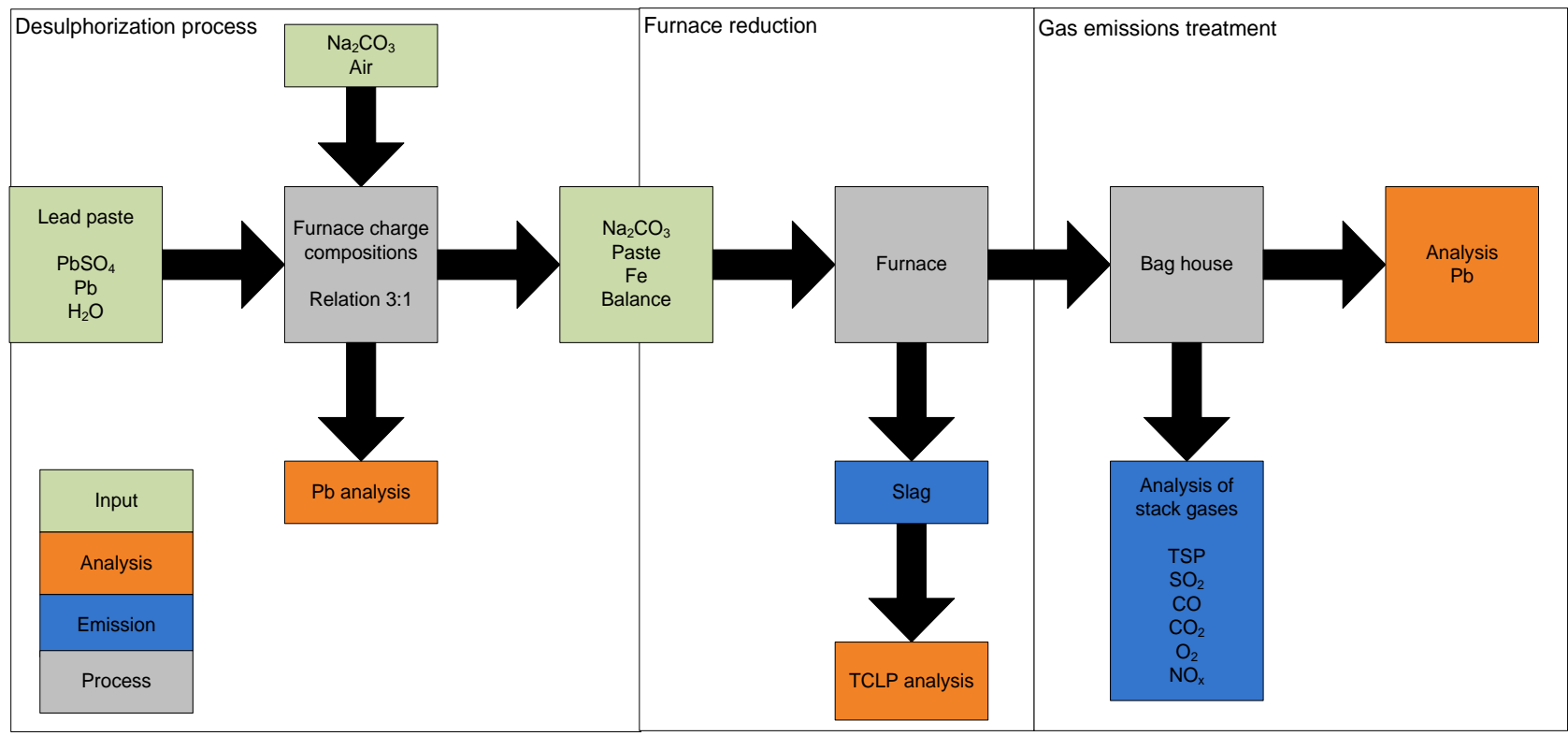

Figure 1. Schematic diagram of the experimental process in PB Metal S.A. 
ciencies. However, because of the limited budget available, we decided to focus our work on tracking the losses of lead, namely the amount of lead present in the bag house dust and stack particulate matter, along with the analysis of the slag (total lead content and TCLP). We define as start point the former furnace's charge composition used in RNP, which was defined as the percentage of anthracite (coke), cast iron and sodium carbonate.

The furnace compositions correspond to [8]-[8]-[5], [7.4]-[7.4]-[5.3] and [5]-[5]-[3]; these numbers indicate the percentage of $\mathrm{Na}_{2} \mathrm{CO}_{3}$, cast iron $(\mathrm{Fe})$ and anthracite in each charge, respectively. For example, a furnace's charge named [8]-[8]-[5] was composed with $8 \% \mathrm{Na}_{2} \mathrm{CO}_{3}, 8 \% \mathrm{Fe}$ and $5 \%$ anthracite. The rest of the charge was composes of lead containing materials, formed mainly of metallic lead and lead paste. The final charge was mixed thoroughly and dries in an open air container before being introduced into the furnace. Desulfurized lead paste (hydrometallurgical process) and non-desulfurized lead paste (pyro-metallurgical process) were evaluate separately.

Typically, the composition of each charge was at least $79 \%$ in lead bearing materials. The optimization of the process was carried out by varying the amount of these materials in order to achieve a more efficient reduction process in the furnace (i.e. a lesser amount of lead lost during the process). PB Metals operates under a batch production system, where every batch requires 4 hours to be completed. In this study, we had only one furnace available. Desulphurization of the lead paste was achieved by using a hydrometallurgical process and sodium carbonate as the desulphurization agent. The waste characterization of the traditional process (pyro-metallurgical only) and the hydrometallurgical modified process included the total lead content in the sulphidic slag, the lead content in the bag house ashes, the TCLP test, and $\mathrm{SO}_{2}$ concentrations in the stackremissions. The analyses of the bag house ashes and the slag were done by acid digestion and atomic absorption (AA). In each case, $0.5-1.0 \mathrm{~g}$ of the solid material was homogenized and acid digested in a microwave digestion system CEM MARS 5 (CEM, USA). An atomic absorption spectrophotometer ZEEnit 700P was used for the lead quantitative analysis (Analytical Jena, Germany). The bag house dust and the slag were collected after every batch was completed. The toxicity characteristic leaching procedure (TCLP) was applied to the slag according to United States Environmental Protection Agency (US-EPA) Method $1311[12]$.

The stack gas analyses were done according to US-EPA stationary source emissions test methods [12]. A TESTO 350 (Testo AG, Germany) flue gas analyzer was used for the analysis of $\mathrm{SO}_{2}$ concentrations and flue gas concentrations, whereas an APEX XC-522 isokinetic sampler (Apex Instruments, USA) was used for the total suspended particulate matter (TSP) sampling. Stack gas and particulate matter sampling was carried out during the furnace operation and until every batch was completed. The lead content in the particulate matter $(\mathrm{P}-\mathrm{Pb})$ matter was extracted by acid digestion and analyzed by atomic absorption (AA) as described above. 


\section{Results and Discussion}

Table 1 shows the results the $\mathrm{SO}_{2}$ analysis in the stack emissions for each process, namely for the processes using desulfurized lead paste and non-desulfurized lead paste.

$\mathrm{SO}_{2}$ emissions were reduce $47 \%, 86 \%$ and $21 \%$ for the furnace charge compositions [5]-[5]-[3], [7.4]-[7.4]-[5.3] and [8]-[8]-[5], respectively, when using the desulfurized lead paste. The results indicate an acceptable efficiency for the implemented desulphurization process. The second furnace charge composition (i.e. [7.4]-[7.4]-[5.3]) showed a major decrease in the $\mathrm{SO}_{2}$ concentrations related with a better furnace efficiency. This composition was formerly identified by $\mathrm{PB}$ Metals as the most efficient composition to recover lead. For the [8]-[8]-[5] charge composition, the $\mathrm{SO}_{2}$ emissions decrease was close to $20 \%$, which could be explained by a deficient $\mathrm{Na}_{2} \mathrm{CO}_{3}$ agitation process or because an excess of lead paste in the furnace charge. The excess of lead paste in the initial charge leads to a less $\mathrm{PbCO}_{3}$ formation and an increase of the $\mathrm{SO}_{2}$ content [14]. According to Costa Rica's environmental regulations, the $\mathrm{SO}_{2}$ concentration in the stack emissions from furnace charge composition [7.4]-[7.4]-[5.3] and [8]-[8]-[5] (under desulphurization conditions) are according to the permissible limits (maximum value $2500 \mathrm{mg} / \mathrm{Nm}^{3}$ ); nevertheless, in the second and third furnace charge composition using the non-desulfurized lead paste the values are close to the limit $\left(2500 \mathrm{mg} / \mathrm{Nm}^{3}\right)$. In the case of the charge composition [5]-[5]-[3], only when the desulfurized lead paste was used, the country regulatory standards were met.

Table 2 shows the total lead content in the bag house ashes. There was not a significant variation of the total lead content when comparing the 3 furnace charge compositions for both processes (with desulphurization and without desulphurization). However, the total lead content in the bag house were greater for those furnace charges that used desulfurized lead paste. The small increase of the lead content when using the desulfurized lead paste for the individual

Table 1. $\mathrm{SO}_{2}$ analysis in the stack emissions for each evaluated process and furnace charge composition.

\begin{tabular}{cccc}
\hline \multirow{2}{*}{$\begin{array}{c}\text { Furnace Charge } \\
\text { Composition }\end{array}$} & Non-desulfurized lead paste & Desulfurized lead paste & $\Delta \mathrm{SO}_{2}$ \\
\cline { 2 - 4 } & $\mathrm{SO}_{2}\left[\mathrm{mg} / \mathrm{Nm}^{3}\right]$ & $\mathrm{SO}_{2}\left[\mathrm{mg} / \mathrm{Nm}^{3}\right]$ & $\mathrm{SO}_{2}\left[\mathrm{mg} / \mathrm{Nm}^{3}\right]$ \\
\hline$[5]-[5]-[3]$ & $3064 \pm 189$ & $1643 \pm 101$ & $-1421 \pm 101$ \\
{$[7.4]-[7.4]-[5.3]$} & $2149 \pm 133$ & $299 \pm 18$ & $-1850 \pm 134$ \\
{$[8]-[8]-[5]$} & $1366 \pm 84$ & $1078 \pm 67$ & $-288 \pm 18$ \\
\hline
\end{tabular}

Table 2. Total lead content in the bag house ashes expressed in $\% \mathrm{~m} / \mathrm{m}$.

\begin{tabular}{cccc}
\hline \multirow{2}{*}{ Furnace Charge Composition } & Non-desulfurized lead paste & Desulfurized lead paste & \multirow{2}{*}{$\Delta \% \mathrm{~Pb}$} \\
\cline { 2 - 4 } & $\% \mathrm{~m} / \mathrm{m}$ & $\% \mathrm{~m} / \mathrm{m}$ & \\
\hline$[5]-[5]-[3]$ & 74.1 & 76.2 & 2.1 \\
{$[7.4]-[7.4]-[5.3]$} & 65.3 & 67.5 & 2.2 \\
{$[8]-[8]-[5]$} & 55.2 & 59.2 & 4.0 \\
\hline
\end{tabular}


charges could be related with the increase of the lead oxides content during the desulphurization stage. In general the lead concentration was stable $(\Delta \% \mathrm{~Pb}<$ $5 \%$ ) in every single charge.

For pyro-metallurgical processes, the Basel Convention has set a total lead content in the ash of approximately $65 \% \mathrm{~m} / \mathrm{m}$ [13]. In the case of the furnace charge composition [7.4]-[7.4]-[5.3] with and without the desulfurized paste, our results are very close to the Basel Convection limit of $65 \% \mathrm{~m} / \mathrm{m}$. The [8]-[8]-[5] furnace composition with the non-desulfurized paste presents the lowest lead concentration in the ash, with a valued of $55.2 \%$. In the case of the formula [5]-[5]-[3], the concentrations are over the limit for both processes, with $74.1 \%$ (without desulphurization) and 76.2\% (with desulphurization). It's important to point out that the small increase of the lead content when using the desulfurized paste could be related with the increase of the lead oxides during the desulphurization process [14].

Table 3 shows the total lead concentrations in the slag. In the non-desulfurized lead paste, the lead concentrations were $1.95 \%, 1.92 \%$, and 1.87 , for the formulas [5]-[5]-[3], [7.4]-[7.4]-[5.3], and [8]-[8]-[5], respectively. In the case of the desulfurized lead paste, the values between each single formula used were also very similar. In general, there is a small increase in the lead concentration when using the desulfurized paste.

Calvo et al. [14] concluded that a slag with high content of $\mathrm{Fe}_{2} \mathrm{O}$ and $\mathrm{Fe}_{3} \mathrm{O}$ (named as magnetite) increases the slag viscosity making the lead decantation less efficient, therefore the lead remains in the slag. According to the authors, one reason of this phenomenon could be associated with the furnace operation, related with a low reduction potential in the furnace, increasing the content of magnetite and hence the slag lead content. However, Calvo et al. [14] recommended values between $2 \%$ and $3 \%$ of lead concentration in the slag as a permissible mean concentration values. Based on this premise, PB Metals furnace operation has an acceptable performance.

Table 4 presents the lead concentrations in the slag lixiviate (TCLP test). The

Table 3. Total lead content in the sulphidic slag expressed in $\% \mathrm{~m} / \mathrm{m}$.

\begin{tabular}{ccc}
\hline \multirow{2}{*}{ Furnace Charge Composition } & Non-desulfurized lead paste & Desulfurized lead paste \\
\cline { 2 - 3 } & $\pm 0.05 \%(\mathrm{~m} / \mathrm{m})$ & $\pm 0.05 \%(\mathrm{~m} / \mathrm{m})$ \\
\hline$[5]-[5]-[3]$ & 1.95 & 2.76 \\
{$[7.4]-[7.4]-[5.3]$} & 1.92 & 2.65 \\
{$[8]-[8]-[5]$} & 1.87 & 2.05 \\
\hline
\end{tabular}

Table 4. Lead concentration in the slag lixiviates based on the TCLP test.

\begin{tabular}{ccc}
\hline \multirow{2}{*}{ Furnace Charge Composition } & \multicolumn{2}{c}{$\mathrm{mg} / \mathrm{L} \mathrm{Pb}$} \\
\cline { 2 - 3 } & Non-desulfurized lead paste & Desulfurized lead paste \\
\hline$[5]-[5]-[3]$ & 56.2 & 1.61 \\
{$[7.4]-[7.4]-[5.3]$} & 52.8 & Not detected \\
{$[8]-[8]-[5]$} & 53.5 & Not detected \\
\hline
\end{tabular}


non-desulfurized paste lead content was very high compared with the US-EPA limit (5 ppm) showing a mean of $54.2 \mathrm{ppm}$.

In the case of the desulfurized paste, the TCLP values obtained for the 3 furnace charges compositions were under the US-EPA limit of $5 \mathrm{ppm}$. The difference between both processes could be associated to the decrease of sulfate content $\left(\mathrm{SO}_{4}^{2-}\right)$ during the desulphurization process as well as the decrease of FeS. This situation allows the slag to tolerate more easily acid conditions. Once the FeS is solubilized, the lead retained in the slag will be released. Therefore when using desulfurized paste, a low concentration of FeS in the slag is obtained (comparing with the non-desulfurized paste), hence a greater lead concentration is retained in the slag, providing a lower lead lost, because there is a small quantity of lead in the cationic form to be lixiviated.

Finally, an economic evaluation of both processes was done in order to establish the feasibility of using the new hydrometallurgical process in PB Metals. Using the furnace charge composition [7.4]-[7.4]-[5.3] as reference, the implementation of the hydrometallurgical process involves an increase of $\sim 10 \%$ in the operational costs (i.e. about US \$ 200 per charge). Based on historic records available at the company, the [7.4]-[7.4]-[5.3] furnace formula has overall lead recovery efficiency of $70 \%$. We estimated that the desulphurization process increased this efficiency in only $1 \%$ when the same formula was used meaning that the increment in the operational costs cannot be compensated directly from the increment in the lead production. Another issue is the increment in the processing time of the lead bearing materials. The desulphurization process takes about 5 hours for completion, which means that PB Metals would need to increase the existing lead inventories to be able to feed the furnace at the same rate they do now. Nevertheless, the hydrometallurgical process implementation could also provide environmental benefits for PB Metals, for example, a decrease in the treatment costs of the sulphidic slag, the largest contributor to waste material [11].

\section{Conclusions}

Based on the analysis of $\mathrm{SO}_{2}$ of the stack emissions, the desulphurization process was highly effective for the evaluated furnace charge compositions. According to Costa Rica's environmental regulation, the $\mathrm{SO}_{2}$ emissions from furnace charge composition [7.4]-[7.4]-[5.3] and [8]-[8]-[5] (under desulphurization conditions) are according to the permissible limits $\left(2500 \mathrm{mg} / \mathrm{Nm}^{3}\right)$. Nevertheless, for the case of the non-desulfurized lead paste, the values are very close to the limit for second and third furnace charge composition. The results of the total lead content in the baghouse ash indicate that there was not a significant variation of the total lead content when comparing the selected furnace charge compositions for both processes (with desulphurization and without desulphurization). However, the total lead content in the bag house was greater for each furnace charge with the desulfurized lead paste. For similar processes, the Basel Convention recommends a total lead content in the ash of approximately $65 \%(\mathrm{~m} / \mathrm{m})$. In the case of 
the furnace charge composition [7.4]-[7.4]-[5.3] with and without the desulfurized paste, the results are very close to the Basel Convection limit. The lead concentrations in the slag lixiviate (TCLP test) for the non-desulfurized paste was very high compared with the US-EPA limit (5 ppm) showing an average of $54.2 \mathrm{ppm}$. In the case of the desulfurized paste, the TCLP values obtained for the evaluated furnace charges composition were under the US-EPA recommended limit.

Despite the fact that the implementation of this hydrometallurgical process before the traditional pyro-metallurgical process could lead to an increment in the operational costs of for PB Metals, it should not be overlooked the related environmental benefits of its application. In the future, the combination of both processes could also render economic benefits, for example, a reduction in the treatment of hazardous waste like the sulphidic slag [15].

\section{References}

[1] Malak, D., Rodak, A., Studnicka, A. and Soszyński, W. (2012) Comparative Analysis of Two Processes for Desulphurization of Battery Paste. Journal of Achievements in Materials and Manufacturing Engineering, 55, 855-859.

[2] Chen, T.T. and Dutrizac, J.E. (1996) The Mineralogical Characterization of LeadAcid Battery Paste. Hydrometallurgy, 40, 223-245.

https://doi.org/10.1016/0304-386X(94)00081-D

[3] Andrews, D., Raychaudhuri, A. and Frias, C. (2000) Environmental Sound Technologies for Recycling Secondary Lead. Journal of Power Sources, 88, 124-129. https://doi.org/10.1016/S0378-7753(99)00520-0

[4] Malak, D. (2010) Comparative Analysis Processes for Desulphurization of Battery Paste. MSc Thesis. (In Polish)

[5] Atanasova, D., Lyakov, N., Vassilev, V., Angelov, G. and Haralampiev, G. (2008) Desulphurization of Lead Cake by Sodium Carbonate and Sodium Hydroxide. Journal of the University of Chemical Technology and Metallurgy, 43, 267-252.

[6] Smaniotto, A., Antunes, A., do Nascimento Filho, I., Dornelles Venquiaruto, L., de Oliveira, D., Mossi, A., Di Luccio, M., Treichel, H. and Dallago, R. (2009) Qualitative Lead Extraction from Recycled Lead-Acid Batteries Slag. Journal of Hazardous Materials, 172, 1677-1680. https://doi.org/10.1016/j.jhazmat.2009.07.026

[7] European Patent Specification (1999) Process for the Recovery of Sulphur from Lead-Acid Battery Scrap. EP1140700B1.

[8] Yanakieva, V.P., Haralampiev, G.A. and Lyakov, N.K. (2000) Desulphurization of the Damped Lead Battery Paste with Potassium Carbonate. Journal of Power Sources, 85, 178-180. https://doi.org/10.1016/S0378-7753(99)00398-5

[9] Begum, D.A, Islam, M.F. and Biswas, R.K. (1989) A Study on the Dissolution of Lead Sulphate from Waste Batteries with Ethanolamines. Hydrometallurgy, 22, 259266. https://doi.org/10.1016/0304-386X(89)90056-X

[10] Sonmez, M.S. and Kumar, R.V. (2009) Leaching of Waste Battery Paste Components, Leaching and Desulphurisation of $\mathrm{PbSO}_{4}$ by Citric Acid and Sodium Citrate Solution. Hydrometallurgy, 95, 82-86. https://doi.org/10.1016/j.hydromet.2008.04.019

[11] Lewis, A.E. and Beautement, C. (2002) Prioritising Objectives for Waste Reprocessing: A Case Study in Secondary Lead Refining. Waste Management, 22, 677-685. 
https://doi.org/10.1016/S0956-053X(02)00012-0

[12] United States Environmental Protection Agency (US-EPA) Emissions Measurement Center, NSPS Method (40 CFR Part 60, Appendix A), Washington DC.

https://www.epa.gov/emc

[13] Basel Convention (2003) Technical Guidelines for the Environmentally Sound Management (ESM) of Wastes Consisting of, Containing or Contaminated with Lead. http://archive.basel.int/pub/techguid/wasteacid-s.pdf

[14] Calvo, F. and Ballester, A. (1987) Pérdidas de plomo en la escoria de un horno de fusión reductora. Vol. 83, Universidad Complutense, Madrid, 397-406.

[15] Olper, M. and Maccagni, M. (2008) Pb Battery Recycling New Frontiers in Paste Desulphurization and Lead Production, Lead and Zinc, 237-246.

Submit or recommend next manuscript to SCIRP and we will provide best service for you:

Accepting pre-submission inquiries through Email, Facebook, LinkedIn, Twitter, etc. A wide selection of journals (inclusive of 9 subjects, more than 200 journals)

Providing 24-hour high-quality service

User-friendly online submission system

Fair and swift peer-review system

Efficient typesetting and proofreading procedure

Display of the result of downloads and visits, as well as the number of cited articles

Maximum dissemination of your research work

Submit your manuscript at: http://papersubmission.scirp.org/

Or contact ojap@scirp.org 